\title{
Realizacja zajęć wynikających z artykułu 42 Karty Nauczyciela w aspekcie zróżnicowania form aktywności fizycznej
}

\author{
Abstract \\ Implementation of activities under article 42 of Teacher's Charter \\ in terms of diversity of physical activity
}

Since September $1^{\text {st }} 2009$, all teachers have been required to carry out activities under Article 42 of the Teachers' Charter, within working hours. The aim of these activities is to increase educational opportunities for students by working with gifted students or those with learning difficulties, and developing individual interests. Therefore, in the field of school physical education, an additional opportunity has been created for the realisation of a variety of physical activities, including sport, recreation, tourism and health. Referring to the arrangements for the implementation of the working hours, which is mentioned in Article 42, point 2 of the Teacher's Charter, studies have been conducted on a group of 78 physical education teachers in primary, lower secondary and upper secondary schools. The research, carried out by a diagnostic survey at the methodical conference in 2014, aimed at gathering opinions on: forms and areas of the implementation of the activities, assessment of the effectiveness of ongoing didactic and educational forms of activities, and determining whether the activities organised by teachers take into account the needs and interests of students, and fundamental canons of methodology of physical education. Gathered results confirm the thesis of the superiority of sport activities over the recreational ones and low status of health education in the implementation of corrective and compensatory gymnastics. 


\section{Wprowadzenie}

Od 1 września 2009 roku wszyscy nauczyciele w ramach czasu pracy zobowiązani są do realizacji zajęć wynikających z artykułu 42 ustawy Karta Nauczyciela. Zajęcia te nazywane są również przez samych nauczycieli godzinami „karcianymi”. W jaki sposób można zaplanować i realizować tego typu zajęcia?

Rozporządzenie określa wiele możliwości - między innymi że są to zajęcia zwiększające szanse edukacyjne uczniów przeznaczone na pracę z uczniem zdolnym lub z uczniem mającym trudności w nauce oraz zajęcia rozwijające zainteresowania uczniów. Zajęcia te powinny zatem wychodzić naprzeciw indywidualnym potrzebom uczniów poprzez udzielanie im pomocy w przezwyciężaniu trudności, rozwijaniu zdolności lub pogłębianiu zainteresowań, a także poprzez sprawowanie nad nimi opieki, zależnie od potrzeb (por. rozporządzenie MENiS z dnia 12 lutego 2002 r. w sprawie ramowych planów nauczania w szkołach publicznych, Dz.U. z 2002 r. Nr 15, poz. 142 z późn. zm.).

W Karcie Nauczyciela zdefiniowano szczegółowy zakres realizacji zajęć wynikających z artykułu 42 . W ramach czasu pracy, o którym mowa w ust. 1, oraz ustalonego wynagrodzenia nauczyciel obowiązany jest realizować:

1) zajęcia dydaktyczne, wychowawcze i opiekuńcze, prowadzone bezpośrednio z uczniami lub wychowankami albo na ich rzecz;

2) inne zajęcia i czynności wynikające z zadań statutowych szkoły, w tym zajęcia opiekuńcze i wychowawcze uwzględniające potrzeby i zainteresowania uczniów, z tym że w ramach tych zajęć: a) nauczyciel szkoły podstawowej i gimnazjum, w tym specjalnych, jest obowiązany prowadzić zajęcia opieki świetlicowej lub zajęcia w ramach godzin przeznaczonych w ramowych planach nauczania do dyspozycji dyrektora szkoły, z wyjątkiem godzin przeznaczonych na zwiększenie liczby godzin obowiązkowych zajęć edukacyjnych, w wymiarze 2 godzin w tygodniu, b) nauczyciel szkoły ponadgimnazjalnej, w tym specjalnej, jest obowiązany prowadzić zajęcia w ramach godzin przeznaczonych w ramowych planach nauczania do dyspozycji dyrektora szkoły, z wyjątkiem godzin przeznaczonych na zwiększenie liczby godzin obowiązkowych zajęć edukacyjnych, w wymiarze 1 godziny w tygodniu (Znowelizowana Karta Nauczyciela 2011, s. 33-34).

Zajęcia pozalekcyjne stanowią ograniczoną część całej dydaktyczno-wychowawczej pracy szkoły. Są ważnym czynnikiem sprzyjającym pogłębianiu nauczania i wychowania oraz kształcenia czynnej postawy uczniów wobec otaczającej rzeczywistości. Zajęcia pozalekcyjne są to zajęcia dzieci i młodzieży organizowane przez szkołę, przy czynnym udziale uczniów, wybrane przez nich jako forma spędzenia wolnego czasu, dające rozrywkę i wypoczynek oraz doskonalące:

- poprzez rozwijanie zainteresowań w różnych dziedzinach nauki, techniki, sztuki i sportu,

- poprzez wyrobienie umiejętności i nawyków, stosowanie wiedzy w praktyce i rozwijanie talentów i uzdolnień,

- poprzez rozwijanie aktywności i samodzielności oraz umiejętności życia w szkole (Bereźnicki 2007, s. 345). 
W takim ujęciu zajęcia pozalekcyjne realizowane z art. 42 Karty Nauczyciela stanowić mogą wyzwanie dla nauczycieli wychowania fizycznego, którzy w swojej ofercie dla ucznia mogą uwzględniać zróżnicowane formy aktywności fizycznej z użyciem dowolnych środków kultury fizycznej.

Główne środki kultury fizycznej to działalność sportowa, rekreacja i rehabilitacja, zatem z nich przede wszystkim winno czerpać wychowanie fizyczne. Aby jednak właściwie te środki wykorzystywać, należy poznać istotę sportu, rekreacji i rehabilitacji (Tatarczuk 2011, s. 11-12).

\section{Cel badań}

Celem badań było uzyskanie opinii nauczycieli na temat stosowanych przez nich praktycznych rozwiązań pedagogicznych i zapatrywań związanych z realizacją godzin wynikających z art. 42 Karty Nauczyciela. Badania sondażowe miały wykazać:

- Czy realizacja zajęć wynikających z art. 42 Karty Nauczyciela cieszy się akceptacją ze strony nauczycieli wychowania fizycznego?

- Jakie formy realizacji zajęć wynikających z art. 42 są dla nauczycieli najbardziej pożądane? W jakich obszarach kultury fizycznej mieszczą się formy zajęć „karcianych"?

- Jakie czynniki zwiększają efektywność zajęć wynikających z art. 42?

- Czy zajęcia dodatkowe cieszą się zainteresowaniem ze strony uczniów (frekwencja)?

- Czy specyfika pracy pedagogicznej (typ szkoły) różnicuje w określonych kwestiach opinie nauczycieli dotyczące realizacji zajęć wynikających z art. 42?

\section{Materiał i metoda badawcza}

Materiał badawczy stanowiła grupa czynnych zawodowo nauczycieli wychowania fizycznego. Badania prowadzono podczas konferencji metodycznych we wrześniu 2014 roku w Miejskim Ośrodku Edukacji Nauczycieli w Bydgoszczy. Jako metody badawczej użyto sondażu diagnostycznego (78 nauczycieli szkół podstawowych, gimnazjalnych i ponadgimnazjalnych) o charakterze pytań zamkniętych. Zmienne niezależne określone zostały poprzez kryterium typu szkoły.

Zmienne zależne zawierały się w procentowym zestawieniu opinii respondentów, w świetle zagadnień dotyczących pytań ankiety. Uzyskane wskaźniki empiryczne (zaznaczone możliwości odpowiedzi jedno- lub wieloelementowe) pozwoliły na dostrzeżenie dynamiki zmian poglądów badanych w zależności od typu szkoły, w której pracują. Istotność różnic pomiędzy zmiennymi niezależnymi weryfikowana była za pomocą nieparametrycznego testu Chi-kwadrat (Krzysztofiak, Urbanek 1977, s. 255). 


\section{Wyniki badań i wnioski}

Tabela 1. Jakie formy realizacji zajęć wynikających z art. 42 Karty Nauczyciela uważa Pani/Pan za najbardziej pożądane?

\begin{tabular}{|c|c|c|c|c|}
\hline Odpowiedzi & Ogółem & $\begin{array}{c}\text { Nauczyciele szkół } \\
\text { podstawowych }\end{array}$ & $\begin{array}{c}\text { Nauczyciele szkół } \\
\text { gimnazjalnych }\end{array}$ & $\begin{array}{c}\text { Nauczyciele szkół } \\
\text { ponadgimnazjalnych }\end{array}$ \\
\hline (a) & 66,7 & 48,4 & 85,0 & 74,1 \\
\hline (b) & 29,5 & 48,4 & 25,0 & 11,1 \\
\hline (c) & 51,3 & 80,6 & 60,0 & 18,5 \\
\hline
\end{tabular}

(Dane w \%; N = 78; wybór jednej lub więcej możliwości)

Objaśnienie:
a) zajęcia dydaktyczne
b) zajęcia wychowawcze,
c) zajęcia opiekuńcze.

Zestawiając uzyskane dane w tablicach czteropolowych, można zauważyć określone różnice pomiędzy wypowiedziami nauczycieli reprezentujących różne typy szkół. Przykładowo porównując wybrane możliwości w zakresie odpowiedzi (a), należy stwierdzić, że istnieje znamienna różnica statystyczna w układzie: nauczyciele szkół podstawowych - nauczyciele gimnazjów $\left(X_{\text {emp. }}^{2}=4,2>X_{\text {teoret. }}^{2}\right.$ $=3,841)$ oraz nauczyciele szkół podstawowych - nauczyciele szkół ponadgimnazjalnych $\left(x_{\text {emp. }}^{2}=13,9>x_{\text {teoret. }}^{2}=3,841\right)$. W tym świetle dla pierwszego układu w obszarze zmiennych niezależnych wyszczególniono:

Tabela 2. Porównanie odpowiedzi dotyczącej realizacji zajęć dydaktycznych w zależności od typu szkoły

\begin{tabular}{|l|c|c|c|}
\hline \multicolumn{1}{|c|}{ Odpowiedzi } & $\begin{array}{c}\text { Nauczyciele szkół } \\
\text { podstawowych }\end{array}$ & $\begin{array}{c}\text { Nauczyciele szkół } \\
\text { gimnazjalnych }\end{array}$ & Razem \\
\hline Zaznaczenie możliwości (a) & 15 & 20 & 35 \\
\hline $\begin{array}{l}\text { Zaznaczenie innych } \\
\text { możliwości niż (a) }\end{array}$ & 38 & 8 & 46 \\
\hline Razem & 53 & 28 & 81 \\
\hline
\end{tabular}

(Dane w liczbach)

$$
\chi^{2}=\frac{(\mathrm{ad}-\mathrm{bc})^{2}}{(a+b)(c+d)(a+c)(b+d)} \cdot N=4,2
$$

Powyższe dane świadczą o tym, że nauczyciele gimnazjów i szkół ponadgimnazjalnych w ramach realizacji godzin dodatkowych bardziej aniżeli nauczyciele 
szkół podstawowych kładą nacisk na dydaktykę przedmiotu. Oczywiście zachodzi tutaj zależność odwrotna wskazująca na przewagę akcentowania form wychowawczych i opiekuńczych w szkołach podstawowych w stosunku do pozostałych placówek. Takie podejście nauczycieli szkół podstawowych związane jest nierozerwalnie z kategorią wieku rozwojowego podopiecznych, którzy znajdują się na początku swej drogi edukacyjnej i wymagają pierwszeństwa działań wychowawczych i opiekuńczych nad dydaktycznymi.

Tabela 3. Czy Pani/Pana zdaniem zwiększenie liczby godzin zajęć edukacyjnych

\begin{tabular}{|c|c|c|c|c|}
\hline Odpowiedzi & Ogółem & $\begin{array}{c}\text { Nauczyciele szkół } \\
\text { podstawowych }\end{array}$ & $\begin{array}{c}\text { Nauczyciele szkół } \\
\text { gimnazjalnych }\end{array}$ & $\begin{array}{c}\text { Nauczyciele szkół } \\
\text { ponadgimnazjalnych }\end{array}$ \\
\hline (a) & 37,2 & 38,7 & 40,0 & 33,4 \\
\hline (b) & 23,1 & 29,0 & 20,0 & 18,5 \\
\hline (c) & 21,7 & 19,4 & 15,0 & 29,6 \\
\hline (d) & 16,7 & 12,9 & 25,0 & 14,8 \\
\hline (e) & 1,3 & - & - & 3,7 \\
\hline
\end{tabular}

(Dane w \%; N = 78; wybór jednej możliwości)

Objaśnienie:

a) mija się z celem, ponieważ uczniowie mają zbyt wiele zajęć w szkole,

b) jest koniecznym wyznacznikiem rozwijania zainteresowań uczniów,

c) jest pożądaną formą pracy z uczniem o specyficznych potrzebach edukacyjnych,

d) jest kolejną zmianą dla zmiany poprzez wprowadzanie nowych rozwiązań,

e) trudno mi powiedzieć.

Jak wynika z powyższej tabeli, 37,2\% nauczycieli uznaje jako bezcelowe wprowadzanie zwiększonej liczby godzin na zajęcia edukacyjne w szkole.

A przecież w procesie wychowania fizycznego, przygotowując młodego człowieka do samodzielnego uczestnictwa w kulturze fizycznej, realizuje się różnorodne cele, dotyczące zarówno dyspozycji kierunkowych, jak i instrumentalnych osobowości wychowanka. By kompleksowo zbadać skuteczność owego procesu, należy oceniać możliwie wszystkie kategorie oczekiwanych rezultatów (Frołowicz 1994, s. 13).

Jednak 23,1\% nauczycieli podkreśla celowość wprowadzenia godzin „karcianych" jako koniecznego wyznacznika rozwijania zainteresowań uczniów. Akceptują tym samym zawarte w Karcie Nauczyciela uzasadnienie, że są to zajęcia zwiększające szanse edukacyjne uczniów przeznaczone na pracę z uczniem zdolnym lub z uczniem mającym trudności w nauce oraz zajęcia rozwijające zainteresowania uczniów. Zajęcia te powinny zatem wychodzić naprzeciw indywidualnym potrzebom uczniów poprzez udzielanie im pomocy w przezwyciężaniu trudności, rozwijaniu zdolności lub pogłębianiu zainteresowań, a także poprzez sprawowanie nad nimi opieki, zależnie od potrzeb (por. Znowelizowana Karta Nauczyciela 2011, s. 33). 
Być może brak społecznego uznania i wsparcia dla realizacji słusznych celów wychowania fizycznego i zdrowotnego powoduje ograniczenie procesu ich realizacji do warstwy instrumentalnej, choć dające wymierne efekty, np. w postaci sukcesów sportowych garstki reprezentantów szkoły, którzy dzięki swym wrodzonym predyspozycjom reprezentują szkołę wszędzie i we wszystkim (Bronikowski 2008, s. 16).

Tabela 4. W jakim obszarze kultury fizycznej znajduje się wybrana przez Panią/Pana forma zajęć „karcianych”?

\begin{tabular}{|c|c|c|c|c|}
\hline Odpowiedzi & Ogółem & $\begin{array}{c}\text { Nauczyciele szkół } \\
\text { podstawowych }\end{array}$ & $\begin{array}{c}\text { Nauczyciele szkół } \\
\text { gimnazjalnych }\end{array}$ & $\begin{array}{c}\text { Nauczyciele szkół } \\
\text { ponadgimnazjalnych }\end{array}$ \\
\hline (a) & 48,7 & 41,9 & 55,0 & 51,9 \\
\hline (b) & 26,9 & 19,4 & 40,0 & 25,9 \\
\hline (c) & 5,1 & 9,7 & 5,0 & - \\
\hline (d) & 2,6 & 3,2 & - & 3,7 \\
\hline (e) & 16,7 & 25,8 & - & 18,5 \\
\hline
\end{tabular}

(Dane w \%; N = 78; wybór jednej możliwości)
Objaśnienie:
a) sport,
b) rekreacja,
c) rehabilitacja,
d) turystyka,
e) zdrowie.

Większość respondentów (48,7\%) realizuje w ramach zajęć „karcianych” formę aktywności fizycznej z akcentem na sport. Wybór ten można uzasadnić tym, że „Człowiek, zwłaszcza młody, nosi w sobie skłonność do sprawdzania się, konfrontowania swoich możliwości z innymi. Sport właśnie stwarza taką okazję, bowiem współzawodnictwo jest atrybutem praktyki sportowej. Dobrze organizowane współzawodnictwo służy rozwojowi człowieka i sprzyja jego harmonijnemu wzrostowi. Dzieje się inaczej, gdy współzawodnictwo i rywalizacja jest rozumiana jako wysiłek skierowany przeciwko drugiemu człowiekowi. Sport powinien przygotowywać do zwyciężania nie nad innymi, ale nad samym sobą. Bowiem grać trzeba razem, we współpracy z innymi, w pogodnej i uczciwej rywalizacji, a nie przez dążenie do przewagi i zwycięstwa za wszelką cenę. Takie współzawodnictwo prowadzi do wrogości i konfliktu" (Dziubiński 2012, s. 60).

Należy jednak pamiętać, że doskonałą okazją dostarczania dzieciom i młodzieży odpowiedniej dawki ruchu są zajęcia kultury fizycznej w szkole. Zajęcia te powinny spełniać podwójną funkcję - powinny być nie tylko źródłem ruchu, ale również inspiracją do podejmowania i rozwiązywania zadań ruchowych w życiu pozaszkolnym (Umiastowska 1991, s. 1). Tymczasem uprawianie sportu, rekreacja fizyczna, zintensyfikowanie wychowania fizycznego, a także wszelkiej aktywności ruchowej stają się dzisiaj koniecznością (Umiastowska 1991, s. 1). 
Tabela 5. Co dla Pani/Pana stanowi największą trudność w realizacji dodatkowych godzin?

\begin{tabular}{|c|c|c|c|c|}
\hline Odpowiedzi & Ogółem & $\begin{array}{c}\text { Nauczyciele szkół } \\
\text { podstawowych }\end{array}$ & $\begin{array}{c}\text { Nauczyciele szkół } \\
\text { gimnazjalnych }\end{array}$ & $\begin{array}{c}\text { Nauczyciele szkół } \\
\text { ponadgimnazjalnych }\end{array}$ \\
\hline (a) & 29,5 & 25,8 & 25,0 & 37,0 \\
\hline (b) & 26,9 & 29,0 & 25,0 & 25,9 \\
\hline (c) & - & - & - & - \\
\hline (d) & 43,6 & 45,2 & 50,0 & 37,0 \\
\hline (e) & - & - & - & - \\
\hline
\end{tabular}

(Dane w \%; N = 78; wybór jednej możliwości)

Objaśnienie:

a) brak odpowiedniej bazy i środków dydaktycznych,

b) zebranie odpowiedniej grupy uczniów,

c) dokumentowanie, przebieg i analiza pracy,

d) synchronizacja własnego planu zajęć z planem uczniów,

e) trudno mi powiedzieć.

Deklarowane opinie badanych dotyczące trudności w realizacji zajęć dodatkowych wskazują, że większość z nich przyczynę trudności upatruje w synchronizacji własnego planu zajęć z planem uczniów (43,6\%). Problem ten nasila się jeszcze bardziej, kiedy grupa ćwiczeniowa składa się z uczniów różnych klas. Biorąc więc pod uwagę kwestię organizacji, nauczyciele wychowania fizycznego niejednokrotnie dostosowują się do planu uczniów poprzez tzw. bierny czas pracy, czyli oczekiwanie w szkole na realizację zajęć zgodnie z planem wybranej grupy uczniów.

Jak wynika z tabeli $6,48,7 \%$ nauczycieli prowadzi w ramach art. 42 jedną lub kilka form sportowych. Wybór ten potwierdza tezę o wyższości zajęć sportowych nad rekreacyjnymi oraz niski status edukacji zdrowotnej w zakresie realizacji zajęć gimnastyki korekcyjno-kompensacyjnej. Nauczyciele wychowania fizycznego identyfikują się przede wszystkim z realizacją wybranych dyscyplin i konkurencji sportowych, uwzględniając przy tym kalendarz imprez sportowych. Natomiast formy rekreacyjne, turystyka oraz zdrowie odnajdują swoje miejsce w szkolnej edukacji fizycznej okazjonalnie, np. w związku z Dniem Dziecka (wycieczki), imprezami środowiskowymi (turnieje gier zespołowych) oraz zajęciami edukacji zdrowotnej jako modułu wychowania fizycznego.

Mała efektywność edukacji szkolnej w kształtowaniu postaw charakteryzujących się pewną gotowością do podejmowania działań oraz troską o ciało i zdrowie ma swoje konsekwencje nie tylko biologiczne, ale również natury ogólnospołecznej (Bronikowski 2008, s. 17). Uczestnictwo w kulturze fizycznej wymaga społecznego nauczania wzorów i norm. W tym znaczeniu kultura fizyczna jako system społeczny przynależy do systemu społecznego wychowania (Pawłucki 2013, s. 162). 
Tabela 6. Jakiego rodzaju zajęcia prowadzi Pani/Pan w ramach art. 42?

\begin{tabular}{|c|c|c|c|c|}
\hline Odpowiedzi & Ogółem & $\begin{array}{c}\text { Nauczyciele szkół } \\
\text { podstawowych }\end{array}$ & $\begin{array}{c}\text { Nauczyciele szkół } \\
\text { gimnazjalnych }\end{array}$ & $\begin{array}{c}\text { Nauczyciele szkół } \\
\text { ponadgimnazjalnych }\end{array}$ \\
\hline (a) & 48,7 & 45,2 & 45,0 & 55,6 \\
\hline (b) & 34,6 & 35,5 & 35,0 & 33,3 \\
\hline (c) & 5,1 & 6,5 & 5,0 & 3,7 \\
\hline (d) & 2,6 & 3,2 & 5,0 & 3,7 \\
\hline (e) & 9,0 & 9,6 & 10,0 & 3,7 \\
\hline (f) & - & - & - & - \\
\hline
\end{tabular}

(Dane w \%; N = 78; wybór jednej możliwości)

Objaśnienie:

a) jedna lub kilka dyscyplin sportowych,

b) różne formy aktywności ruchowej,

c) jedna lub kilka form tańca,

d) różne formy turystyki,

e) gimnastyka korekcyjno-kompensacyjna,

f) inne...

Tabela 7. Czy realizując zajęcia wynikające z art. 42, osiąga Pani/Pan lepsze efekty w porównaniu z lekcją wychowania fizycznego?

\begin{tabular}{|c|c|c|c|c|}
\hline Odpowiedzi & Ogółem & $\begin{array}{c}\text { Nauczyciele szkół } \\
\text { podstawowych }\end{array}$ & $\begin{array}{c}\text { Nauczyciele szkół } \\
\text { gimnazjalnych }\end{array}$ & $\begin{array}{c}\text { Nauczyciele szkół } \\
\text { ponadgimnazjalnych }\end{array}$ \\
\hline (a) & 23,1 & 25,8 & 20,0 & 22,2 \\
\hline (b) & 3,8 & 6,5 & 5,0 & - \\
\hline (c) & 43,6 & 48,4 & 40,0 & 40,8 \\
\hline (d) & 20,5 & 16,1 & 25,0 & 22,2 \\
\hline (e) & 9,0 & 3,2 & 10,0 & 14,8 \\
\hline
\end{tabular}

(Dane w \%; N = 78; wybór jednej możliwości)

Objaśnienie:

a) tak, ponieważ mam mniejszą grupę uczniów,

b) tak, ponieważ pracuję tylko z jednym uczniem,

c) tak, ponieważ nie mam grup łączonych (dziewczynki z chłopcami, chłopcy różnych klas, dziewczynki różnych klas)

d) nie,

e) trudno mi powiedzieć.

Jak wynika z odpowiedzi zamieszczonych w tabeli 7, nauczyciele deklarują osiąganie lepszych efektów podczas zajęć „karcianych” w porównaniu z lekcją wychowania fizycznego (43,6\%). Większa efektywność zajęć prowadzonych w ramach art. 42 wynika z możliwości tworzenia grup według schematu ustalonego przez nauczyciela, a nie władz oświatowych, które to wielokrotnie w planie organizacyjnym wychowania fizycznego dopuszczają możliwość łączenia grup, nawet koedukacyjnych. 
A przecież rozporządzenie Ministra Edukacji Narodowej z dnia 23 marca 2009 r. w sprawie ramowych planów nauczania w szkołach publicznych określa, że zajęcia z wychowania fizycznego mogą odbywać się w grupach liczących od 12 do 26 uczniów. Dopuszcza się tworzenie grup międzyoddziałowych lub międzyklasowych. W klasach IV-VI szkoły podstawowej i gimnazjum zajęcia wychowania fizycznego mogą być prowadzone oddzielnie dla dziewcząt i chłopców (Dz.U. Nr 54, poz. 442).

Elementem szeroko pojętego warsztatu pedagoga wychowania fizycznego są też uczniowie, ich cielesność, potrzeby, problemy oraz nade wszystko ich kształtująca się osobowość. Stąd płyną wskazówki, jaki ma być warsztat wspomagający ich rozwój i zdrowie. W tworzeniu takiego kreatywnego warsztatu nie uda się zapewne ustrzec przed eklektyzmem, ale on wynika także z różnorodności i zmienności potrzeb w procesie wspomagania rozwoju i zdrowia ucznia we współczesnej szkole (Pańczyk, Warchoł 2006, s. 49-50).

Tabela 8. Czy ma Pani/Pan problemy z frekwencją na zajęciach dodatkowych?

\begin{tabular}{|c|c|c|c|c|}
\hline Odpowiedzi & Ogółem & $\begin{array}{c}\text { Nauczyciele szkół } \\
\text { podstawowych }\end{array}$ & $\begin{array}{c}\text { Nauczyciele szkół } \\
\text { gimnazjalnych }\end{array}$ & $\begin{array}{c}\text { Nauczyciele szkół } \\
\text { ponadgimnazjalnych }\end{array}$ \\
\hline (a) & 48,8 & 64,5 & 65,0 & 18,5 \\
\hline (b) & 15,4 & 12,9 & 10,0 & 22,2 \\
\hline (c) & 35,8 & 22,6 & 25,0 & 59,3 \\
\hline
\end{tabular}

(Dane w \%; N = 78; wybór jednej możliwości)

Objaśnienie:

a) tak, ponieważ uczniowie mają w tym samym czasie możliwość korzystania z innych zajęć,

b) tak, ponieważ zajęcia te nie podlegają ocenie,

c) nie.

Zestawiając uzyskane dane w tablicach czteropolowych, można zauważyć określone różnice pomiędzy wypowiedziami nauczycieli reprezentujących różne typy szkół. Przykładowo porównując wybrane możliwości w zakresie odpowiedzi (a), należy stwierdzić, że istnieje znamienna różnica statystyczna w układzie: nauczyciele szkół podstawowych - nauczyciele szkół ponadgimnazjalnych $\left(\mathrm{X}^{2}\right.$ emp. $=$ $\left.10,8>x_{\text {teoret. }}^{2}=3,841\right)$. W tym świetle dla takiego układu w obszarze zmiennych niezależnych wyszczególniono:

Tabela 9. Porównanie odpowiedzi dotyczącej frekwencji na zajęciach dodatkowych w zależności od typu szkoły

\begin{tabular}{|l|c|c|c|}
\hline \multicolumn{1}{|c|}{ Odpowiedzi } & $\begin{array}{c}\text { Nauczyciele szkół } \\
\text { podstawowych }\end{array}$ & $\begin{array}{c}\text { Nauczyciele szkół } \\
\text { ponadgimnazjalnych }\end{array}$ & Razem \\
\hline Zaznaczenie możliwości (a) & 20 & 5 & 25 \\
\hline $\begin{array}{l}\text { Zaznaczenie innych } \\
\text { możliwości niż (a) }\end{array}$ & 13 & 22 & 35 \\
\hline Razem & 33 & 27 & 60 \\
\hline
\end{tabular}

(Dane w liczbach) 


$$
\chi^{2}=\frac{(\mathrm{ad}-\mathrm{bc})^{2}}{(a+b)(c+d)(a+c)(b+d)} \cdot N=10,8
$$

Powyższe dane świadczą o tym, że nauczyciele szkół podstawowych deklarują większe problemy dotyczące frekwencji podczas zajęć dodatkowych aniżeli nauczyciele szkół ponadgimnazjalnych. Fakt ten można interpretować w dwojaki sposób. Po pierwsze, aktualne przepisy zobowiązują nauczyciela szkoły podstawowej i gimnazjum do prowadzenia zajęć, o których mowa w art. 42 ustawy Karta Nauczyciela, w wymiarze 2 godzin w tygodniu, natomiast nauczyciela szkoły ponadgimnazjalnej w wymiarze 1 godziny tygodniowo (Znowelizowana Karta Nauczyciela 2011, s. 33-34). Po drugie, uczniowie w szkole podstawowej nie potrafią jeszcze dokonywać samodzielnych wyborów w zakresie aktywności fizycznej i częściej kierują się wskazaniem rodziców niż własnym, wewnętrznym przekonaniem o chęci udziału w takiej lub innej formie zajęć.

\section{Podsumowanie}

W toku niniejszych badań dokonano analizy realizacji zajęć wynikających z art. 42 Karty Nauczyciela w aspekcie zróżnicowania form aktywności fizycznej. Jak wykazały badania, nauczyciele prezentują różnorodne opinie na ten temat i są one również uzależnione od typu szkoły, w której pracują. Zebrane opinie potwierdzają tezę o wyższości zajęć sportowych nad rekreacyjnymi oraz zdrowotnymi w zakresie realizacji zajęć gimnastyki korekcyjno-kompensacyjnej. Świadczy to o niskiej świadomości nauczycieli wychowania fizycznego, zwłaszcza tych, którzy w swym warsztacie pedagogicznym uwzględniają tylko sportowe formy aktywności fizycznej. Nie rozumieją przy tym naczelnego przesłania wynikającego z realizacji zajęć „karcianych” - że powinny one wychodzić naprzeciw indywidualnym potrzebom uczniów poprzez udzielanie im pomocy w przezwyciężaniu trudności (w tym zdrowotnych), w rozwijaniu zdolności lub pogłębianiu zainteresowań, a także poprzez sprawowanie nad nimi opieki, zależnie od potrzeb.

Dziś nie wystarczają w działaniu człowieka, a w szczególności w działaniu pedagogicznym nauczyciela, sprawność ruchowa, umiejętności dydaktyczne. Coraz większą rolę zaczynają odgrywać wiedza naukowa i aktywność poznawcza oraz umiejętność wykorzystania tej wiedzy w praktycznym działaniu. Podmiotowi działania bliskie muszą być najnowsze osiągnięcia naukowe w interesującej go dziedzinie działalności. Nauka nabiera szczególnego znaczenia również dlatego, że może skutecznie przeciwdziałać zatraceniu walorów humanistycznych. Może zapobiegać zepchnięciu człowieka do roli przedmiotu dokonujących się przeobrażeń. W związku z tym niezmiernie istotny staje się problem permanentnego samodoskonalenia się. Każdy nauczyciel musi sobie zdawać sprawę z tego, że wiedza zdobyta na uczelni nie stanowi ostatecznej i zamkniętej całości. By jej wartość stale utrzymywała się na wysokim poziomie, trzeba ją systematycznie 
pomnażać i modyfikować. Współczesny nauczyciel wychowania fizycznego nie może zamykać się w ramy ciasnego praktycyzmu, lecz musi przyjmować współodpowiedzialność za rozwój teorii pedagogicznej i dydaktyki oraz za intensywność postępu pedagogicznego. Warunkiem wywiązanie się nauczyciela z tej odpowiedzialności jest:

- wysoki poziom wiedzy ogólnej i specjalistycznej, w tym także wiedzy pedagogicznej,

- umiejętność systematycznego jej wzbogacania i aktualizowania,

- twórcze podejście do pracy, eliminowanie szablonów i przezwyciężanie tendencji dogmatycznych (Bielski 1996, s. 44-45).

\section{Literatura}

Bereźnicki F., Podstawy dydaktyki, Oficyna Wydawnicza „Impuls”, Kraków 2004, s. 345.

Bielski J., Uwarunkowania efektywności pracy nauczyciela wychowania fizycznego, Wyższa Szkoła Pedagogiczna im. Jana Kochanowskiego, Kielce 1996, s. 44-45.

Bronikowski M., Postawy prosomatyczne młodzieży gimnazjalnej jako efekt interwencji edukacyjnej w procesie wychowania fizycznego, Akademia Wychowania Fizycznego im. Eugeniusza Piaseckiego, Poznań 2008, s. 16-17.

Dziubiński Z., Sport jako przestrzeń socjalizacji osoby ludzkiej, [w:] Z. Dziubiński, K. Jankowski (red.) Kultura fizyczna a socjalizacja, Salezjańska Organizacja Sportowa Rzeczpospolitej Polskiej, Warszawa 2012, s. 60.

Frołowicz T., Skuteczność procesu wychowania fizycznego w szkole podstawowej, Akademia Wychowania Fizycznego im. Jędrzeja Śniadeckiego, Gdańsk 1994, s. 13.

Krzysztofiak M., Urbanek D., Metody statystyczne, PWN, Warszawa 1977, s. 255.

Pańczyk W., Warchoł K., W kręgu teorii, metodyki i praktyki współczesnego wychowania fizycznego, Wydawnictwo Uniwersytetu Rzeszowskiego, Rzeszów 2006, s. 49-50.

Pawłucki A., Nauki o kulturze fizycznej, Wydawnictwo Akademii Wychowania Fizycznego we Wrocławiu, Wrocław 2013, s. 162.

Umiastowska D., Lekcja wychowania fizycznego. Skrypt dla studentów wychowania fizycznego, Uniwersytet Szczeciński, Szczecin 1991, s. 1.

Tatarczuk J., Metodyka wychowania fizycznego. Zagadnienia wybrane, Uniwersytet Zielonogórski, Zielona Góra 2011, s. 11-12.

Rozporządzenie Ministra Edukacji Narodowej z dnia 23 marca 2009 r. w sprawie ramowych planów nauczania w szkołach publicznych, Dz.U. Nr 54, poz. 442.

Rozporządzenie MENiS z dnia 12 lutego 2002 r. w sprawie ramowych planów nauczania w szkołach publicznych, Dz.U. z 2002 r. Nr 15, poz. 142 z późn. zm.

Znowelizowana Karta Nauczyciela, Wydawnictwo eMPi², Poznań 2011, s. 33-34. 